\title{
Genetic discrimination legislation in Canada: moving from rhetoric to real debate
}

\author{
Stuart G. Nicholls PhD, Patrick Fafard PhD
}

Competing interests: None declared.

This article has been peer reviewed.

Correspondence to: Stuart Nicholls, snicholls@cheo.on.ca

CMAJ 2016. DOI:10.1503 /cmaj.151170

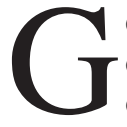
enetic discrimination refers to the perceived unfair differential treatment of individuals based on their genetic constitution. ${ }^{1}$ The context in which this may occur varies, but common situations of discussion include discrimination in securing employment and difficulty obtaining life insurance. The potential for discrimination following genetic testing is a continuing challenge in Canada and elsewhere. Recent attempts at legislation in Canada have been piecemeal, and there has been a lack of detailed investigation regarding the need for additional legislation. There is a need for coordinated discussion between the provinces and the federal government and for detailed analysis of existing evidence and legislation around genetic discrimination to enable evidence-based policy-making.

There has been little argument in favour of the use of genetic test results for human resource decisions; indeed, this would run counter to many social and legal initiatives to support disabled individuals. However, others have contended that the use of genetic test results for the basis of risk assessment (and hence premium setting) for life insurance purposes is appropriate and that not doing so amounts to "genetic exceptionalism" given that other relevant health information may be used. ${ }^{2}$ The counterargument is that life insurance is, in essence, a social good and that individuals should not be penalized for their pure genetic bad luck. ${ }^{3}$ Consequently, they argue that some basic level of life insurance should be universally accessible. ${ }^{4}$ In some countries, mainly in Europe, governments have opted for this latter position and have introduced protections for people who undergo genetic testing. ${ }^{4}$ In the United Kingdom, for example, there is a Concordat and Moratorium between the government and the insurance industry on the use of genetic testing for future illness. That is, information from predictive genetic testing cannot be used for insurance purposes.

In Canada, no specific legislation excepting the use of genetic information exists. ${ }^{5}$ In recent years, various private members' bills were introduced in the federal Parliament and in Ontario that would have prevented the use of genetic information to discriminate against individuals. None of them passed. Bill C-508 was introduced to amend the Canadian Human Rights Act, to protect Canadians from discrimination on the basis of their genetic characteristics. Bill C-536 sought to add the term "genetic characteristics" to the list of prohibitive grounds of discrimination in the Canadian Human Rights Act. Bill 127, entitled the Human Rights Code Amendment Act (Genetic Characteristics), was introduced in 2013 to the Ontario legislature by MPP Michael Colle. ${ }^{6}$ Bill S-201 sought to modify the Canada Labour Code and the Canadian Human Rights Act to prevent insurers and employers from using genetic test results. The federal government under the Harper administration proposed legislation designed to address genetic discrimination issues that fell under federal authority; this Bill C-68 included amendments to the Canadian Human Rights Act, the Privacy Act and the Personal Information Protection and Electronic Documents Act. The changes would have outlawed discrimination on the grounds of genetic test results with respect to matters of employment and the provision of goods, services, facilities and accommodation for federally regulated business and industries. Announced in June 2015, the bill had virtually no chance of being passed given the decision to seek the dissolution of Parliament and the election call in early August. This effectively killed the bill, although comments by the main federal political parties during the election campaign indicated a crossparty commitment to legislative protections for people undergoing genetic testing.?

All editorial matter in CMAJ represents the opinions of the authors and not necessarily those of the Canadian Medical Association. 
It is unclear, however, whether new laws are required. Although no legislation exists at the national level that explicitly prohibits genetic discrimination in Canada, it may be that an individual with a genetic predisposition is protected under the Canadian Human Rights Act (article 3$)^{8}$ or the Canadian Charter of Rights and Freedoms. ${ }^{9}$ Under section 15(1) of the charter, it may be argued that a genetic predisposition could be grounds upon which discrimination is prohibited given previous statements. Such statements have noted that characteristics that are "immutable, difficult to change, or changeable only at unacceptable personal cost" could be prohibited grounds for discrimination. ${ }^{10}$

Furthermore, real debate about genetic discrimination will mean taking a hard look at life insurance underwriting. (Similar concerns may be raised in the context of insurance for critical illness and long-term disability). But this is an area of provincial jurisdiction. This means that legislation proposed by the previous federal government, and the subsequent cross-party support for federal action, bears no impact on other areas of potential risk for genetic discrimination. Even when legislation has been enacted to prohibit genetic discrimination, notably in the United States, the use of genetic information for life insurance underwriting is generally excluded from these prohibitions. The Genetic Insurance Nondiscrimination Act in the US does not cover the use of genetic testing for life insurance. In other jurisdictions, despite protections being put in place, there are exemptions. In the UK, for example, information from predictive genetic testing for Huntington disease can be requested for premiums greater than $£ 500000 .{ }^{10}$ Furthermore, results of genetic testing to confirm a diagnosis or inform treatment can be used. There is also a paucity of evidence regarding the amount of discrimination currently experienced. ${ }^{1}$

We believe there is a need for nuanced discussion regarding the roles and remits of the federal government, the provincial and territorial governments, and industry partners. In particular, we see three key areas for discussion and where progress needs to be made.

First, there is a need for careful debate about the legitimate place for health information in actuarial risk calculations. This goes hand in hand with important questions about the role that life insurance should play in Canadian society. Answers to these questions will be important in determining whether further consideration of specific protections for genetic information is needed.

Second, if there is a characteristic specific to genetic information compared with other types of health information that may warrant additional protection, what is it? Clearly enunciating why genetic information requires protections beyond other health information - information that may be equally stigmatizing or influential in the context of life insurance — will be key.

Third, if it is determined that the current structure of life insurance is desirable, and that genetic information is distinguishable from other health information in a relevant way and requires protection, then there is a need to explore further whether the existing legal regime offers adequate protection to individuals at risk of genetic conditions. Given the earlier suggestion that there may already be constitutional and legal prohibitions on discrimination based on genetic predisposition, it would seem improvident to enact unnecessary new laws.

In addressing each of the above areas, there is a need for evidence, theory (ethical and legal) and, if action is needed, intergovernmental collaboration. Does evidence point to specific areas of concern? Does theory suggest potential ethical or legal solutions? Are the federal and provincial/territorial governments able to craft a collaborative approach? It will be up to the newly elected federal government, working with the provinces, to carefully reconsider the rhetoric and reality of genetic discrimination. Governments can then take proper action regarding the use of genetic information, which leaves open the possibility that truly appropriate action may include no legislative change.

\section{References}

1. Joly Y, Ngueng Feze I, Simard J. Genetic discrimination and life insurance: a systematic review of the evidence. BMC Med $2013 ; 11: 25$.

2. Green MJ, Botkin JR. "Genetic exceptionalism" in medicine: clarifying the differences between genetic and nongenetic tests. Ann Intern Med 2003;138:571-5.

3. Nicholls SG, Joly Y, Moher E, et al. Genetic discrimination and insurance in Canada: Where are we now? Risk 2014;30:46-52.

4. Van Hoyweghen I, Rebert L. Your genes in insurance: from genetic discrimination to genomic solidarity. Personalized Med 2012;9:871-7.

5. Joly Y, Burton H, Knoppers BM, et al. Life insurance: genomic stratification and risk classification. Eur J Hum Genet 2014; 22:575-9.

6. Bill 127, Human Rights Code Amendment Act (Genetic Characteristics), 2nd session, 40th Parliament, Ontario, 2013. Available: www.ontla.on.ca/web/bills/bills_detail.do?locale=en $\&$ Intranet $=\&$ BilliD=2888 (accessed 2016 Jan. 4).

7. Loriggio P. Conservatives would revive bill to ban genetic discrimination: Oliver. Globe and Mail [Toronto] 2015 Oct. 1.

8. Canadian Human Rights Act, RSC 1985, c H-6. Available: http://canlii.ca/t/5266t (accessed 2014 Apr. 14)

9. Otlowski M, Taylor S, Bombard Y. Genetic discrimination: international perspectives. Annu Rev Genomics Hum Genet 2012; 13:433-54.

10. Walker J. Genetic discrimination and Canadian law. Ottawa: Library of Parliament; 2014.

Affiliations: Children's Hospital of Eastern Ontario Research Institute (Nicholls); School of Epidemiology, Public Health and Preventive Medicine (Nicholls), University of Ottawa; Graduate School of Public and International Affairs (Fafard), Institute for Science, Society and Policy (Fafard), and Centre for Health Law, Policy and Ethics (Fafard), University of Ottawa, Ottawa, Ont.

Contributors: Both authors contributed equally to the conception of the article and the writing and critical revision of the manuscript, gave approval of the final version to be published and agreed to act as guarantors of the work. 